\title{
DNA damage response (DDR) and senescence: shuttled inflamma-miRNAs on the stage of inflamm-aging
}

\author{
Fabiola Olivieri ${ }^{1,2}$, Maria Cristina Albertini ${ }^{3}$, Monia Orciani ${ }^{1}$, Artan Ceka ${ }^{1}$, Monica \\ $\mathrm{Cricca}^{4}$, Antonio Domenico Procopio ${ }^{1,2}$ and Massimiliano Bonafè ${ }^{4}$ \\ ${ }^{1}$ Department of Clinical and Molecular Sciences (DISCLIMO), Università Politecnica delle Marche, Ancona, Italy \\ ${ }^{2}$ Center of Clinical Pathology and Innovative Therapy, Italian National Research Center on Aging, INRCA-IRCCS, Ancona, \\ Italy \\ 3 Department of Biomolecular Sciences, Biochemistry and Molecular Biology, Università degli Studi di Urbino "Carlo Bo", \\ Urbino, Italy \\ ${ }^{4}$ Department of Experimental, Diagnostic and Specialty Medicine, DIMES, University of Bologna, Bologna, Italy \\ Correspondence to: Fabiola Olivieri, email: f.olivieri@univpm.it \\ Keywords: microRNA, senescence-associated secretory phenotype, senescence, inflamm-aging, Gerotarget \\ Received: June 18,2015 Accepted: September 17, $2015 \quad$ Published: September 29, 2015
}

This is an open-access article distributed under the terms of the Creative Commons Attribution License, which permits unrestricted use, distribution, and reproduction in any medium, provided the original author and source are credited.

\section{ABSTRACT}

A major issue in aging research is how cellular phenomena affect aging at the systemic level. Emerging evidence suggests that DNA damage response (DDR) signaling is a key mechanism linking DNA damage accumulation, cell senescence, and organism aging. DDR activation in senescent cells promotes acquisition of a proinflammatory secretory phenotype (SASP), which in turn elicits DDR and SASP activation in neighboring cells, thereby creating a proinflammatory environment extending at the local and eventually the systemic level. DDR activation is triggered by genomic lesions as well as emerging bacterial and viral metagenomes. Therefore, the buildup of cells with an activated DDR probably fuels inflamm-aging and predisposes to the development of the major age-related diseases (ARDs). Micro (mi)-RNAs non-coding RNAs involved in gene expression modulation - are released locally and systemically by a variety of shuttles (exosomes, lipoproteins, proteins) that likely affect the efficiency of their biological effects. Here we suggest that some miRNAs, previously found to be associated with inflammation and senescence - miR-146, miR155 , and miR-21 - play a central role in the interplay among DDR, cell senescence and inflamm-aging. The identification of the functions of shuttled senescence-associated miRNAs is expected to shed light on the aging process and on how to delay ARD development.

\section{INTRODUCTION}

The DNA damage response (DDR) is an evolutionarily conserved signaling cascade, activated by DNA damage, which directs cell fate toward DNA repair, senescence, or apoptosis [1]. In higher organisms the DDR is thought to prevent neoplastic transformation in a cell-autonomous manner, by ensuring removal of severely damaged cells [2]. However, emerging data suggest that DDR signaling can also work through a paracrine/systemic mechanism, shaping the systemic environment through regulation of tissue repair and immune responses. Persistent DNA damage signaling (i.e. telomere attrition) may result in the DDR sending "early" and "late" extracellular signals, and in the induction of a senescence-associated secretory phenotype (SASP) $[1,2$, 3]. DDR/SASP signaling involves a variety of biologically active proinflammatory mediators, including interleukins, chemokines, growth factors, matrix-degrading enzymes, and reactive oxygen species (ROS) [4]. Its role in the inflammatory response to tissue damage is epitomized by the observation that the major factors involved the setting up of the secretome are the proinflammatory transcription nuclear factor (NF)-kappaB (NF-kB) and the inflammasome $[5,6,7]$. NF-kB transcriptionally induces a variety of inflammatory SASP components 
(e.g. interleukin [IL]-6, IL-1 and tumor necrosis factor $[\mathrm{TNF}-\alpha])$, which are essential cell-autonomous regulators of senescence $[3,8,9,10,11]$. The SASP components, under the control of the inflammasome, are also able to propagate paracrine senescence to neighboring cells, which become capable of acquiring the SASP phenotype [7]. Senescence can thus spread "senescent cell" by "senescent cell", at the tissue and the systemic level [12]. The identification and characterization of all DDR/ SASP secretome components is thus expected to provide valuable information on the aging process and on how to delay the development of age-related diseases (ARDs). It is reasonable to hypothesize that the age-related increase in the burden of cells with DDR/SASP activation links cell senescence and inflamm-aging, and that non-coding RNA, mainly microRNAs (miRNAs), play a key role in the diffusion of DDR/SASP signaling to surrounding nondamaged cells during human aging, suggesting that the identification of new DDR/SASP signaling components may lead to develop novel therapeutic interventions against ARDs.

\section{Systemic spread of genomic damage: inflamm- aging}

Senescence is a distinctive phenotype of eukaryotic cells involving the loss of replication ability and the acquisition of characteristic features - such as flattening and increased $\beta$-galactosidase (SA- $\beta$-gal) and p16INK expression - in response to a variety of stimuli that induce DNA damage, including extensive in vitro replication [13]. Senescence per se has long been known to be a mechanism halting the replication of cells that have acquired potentially hazardous genetic mutations $[2,14]$. The finding that late-life clearance of senescent cells in a progeroid mouse model attenuates the progression of already established ARDs lends support to the notion that cell senescence is crucially involved in aging [15]. Notably, the same result has been achieved using a combination of molecules (e.g. quercetin and tyrosine kinase inhibitors), confirming the feasibility of selective senescent cell ablation and the effectiveness of senolytic drugs in alleviating symptoms of frailty and in extending health-span [16]. Even though the buildup in normal aged tissues of overtly senescent cells has proved difficult to demonstrate, it appears to have recently been documented in animal models and human tissues. Indeed, an accumulation of SA- $\beta$-gal/p16INK-positive cells has been described in atherosclerotic plaques, peritumor stroma, endothelia exposed to shear stress, in wounds in non-physiological and pathological conditions [17], in astrocytes of patients with Alzheimer's disease [18], and in kidney [19], and skin of old individuals [20]. Notably, the recent, seminal demonstration that DNA damage alone can induce distinct aging phenotypes in mouse liver has provided new insights into the causative role of DDR as a driver of aging [21].

The finding that the DDR is associated with SASP acquisition has further documented the complex relationship among DDR, cellular senescence, aging and ARD development $[22,23]$. Even though "atypical" senescent states may arise independent of DDR activation [24], a wealth of evidence demonstrates that SASP is under the control of the DDR machinery $[13,25]$. Conceivably, the physiological role of SASP is to act as an alarm system triggering the recruitment of immune cells (i.e. NK cells), to clear senescent/damaged cells from tissues [26]. Indeed, the SASP is viewed as an evolutionarily conserved, molecular tissue homeostasis program [27] that exerts beneficial early in life [28]. In adulthood it is held to modulate the remodeling and repair of damaged tissues and to promote the clearance of damaged/senescent cells through activation of innate immune cells [29] Notably, the spread of senescence among "bystander cells" requires DDR activation [30], suggesting that the DDR and the ensuing inflammatory response are crucially involved in the propagation of aging phenotypes at the tissue and systemic levels. The notion is reminiscent of the so called "radiation-induced" bystander effect, where soluble factors from cells exposed to ionizing radiation (IR) or radioactive particles have been seen to activate the DDR machinery in non-exposed cells [31, 32]. A variety of mediators, including inflammatory factors, and NF-kB activation have been implicated in the phenomenon [33, 34]. Recently, it has been suggested that the diffusion of the radiation-induced bystander effect mimics that of radiation-induced senescence [35]. Consequently, DDR activation in a small subset of cells, including stem cells, may be sufficient for local and systemic SASP propagation, fuelling of inflamm-aging, and facilitation of chronic ARD development [36].

\section{Metagenomic tailoring of inflamm-aging}

DDR activation is critical for the replication of cytomegalovirus [37]. Herpes-viruses have long been implicated in a variety of ARDs and associated with mortality in elderly cohorts [38]. Indeed, a broad range of human DNA viruses, including papilloma-viruses, polyoma-viruses, and herpes-viruses, exploit DDR activation for their own replication [37, 39, 40]; given their high prevalence in adulthood, it is reasonable to argue that most aging individuals are exposed to these exogenous DDR inducers in the course of their life. Recent data obtained by high-throughput metagenomics indicate that hundreds of DNA viruses dwell in biological fluids from healthy individuals, suggesting that an extraordinary amount of potential DDR-inducing agents may accrue with aging [41]. Notably, bacteriophages hosted by the local bacterial flora and non human-tropic viruses take part to viral communities isolated from different tissues 
and body compartments [42-44]. Consequently, each individual's metagenomic fingerprint is likely determined by the surrounding environment and ecosystem [41]. This may also include the "atypical" large DNA viruses that infect unicellular eukaryotes (i.e. amebae) [45]. At least in principle, most components of this emerging human virome are not frankly pathogenic, except in extreme conditions, such as immunodepression [46-48]; indeed, some may have evolved to exert protective/symbiotic functions, acting as a sort of virobiota capable of shaping and stimulating the immune system [49, 50]. Interestingly, the immune response and its activation under impaired immune conditions have been proposed as immune senescence mechanisms [51]. The above considerations suggest that virome-driven DDR activation may provide a significant contribution to the buildup of senescent cells, shaping each individual's inflamm-aging trajectory.

\section{MiR-146, miR-21, and miR-155: three key players in the inflamm-aging scenario}

A large number of miRNAs modulate DDR activation and can promote or inhibit senescence and SASP in physiological and pathological conditions [52]. However, evidence regarding miRNA release in connection with DDR activation and/or of SASP acquisition and, especially, information regarding specific
SASP-related secreted miRNAs, is quite limited. It is nonetheless reasonable that DDR/SASP-related miRNAs would share some common features such as: i) differential expression in senescent and young cells, making them senescence-associated (SA)-miRNAs; ii) the ability to modulate inflammatory pathways, primarily the NF-kB pathway, making them inflamma-miRNAs; iii) differential expression in total plasma/serum or in microparticles/ exosomes of patients with the major ARDs; and iv) significant modulation induced by bacterial and viral infections. In this regard, virus-synthesized miRNAs can themselves target NF-kB, suggesting that metagenomeand genome-driven mechanisms both converge on the host inflammatory response [53]. At least three miRNAs - miR-146a, miR-155 and miR-21 - are consistent with this scenario and may constitute an SA/inflamma-miRNA system that can affect the systemic proinflammatory status and exert adverse effects on the pathways and mechanisms involved in organismal homeostasis [54-57].

\section{miR-146}

MiRNAs of the 146 family, including miR-146a and miR-146b, share all the above features. MiR-146a is one of the major miRNAs involved in orchestrating immune and inflammatory signaling via modulation of NF-kB activation and targeting of IL-1 receptor associated kinase (IRAK1 and 2) and TNF receptor-associated factor 6 (TRAF6) [58]. Intriguingly, miR-146a is an NF-kB-

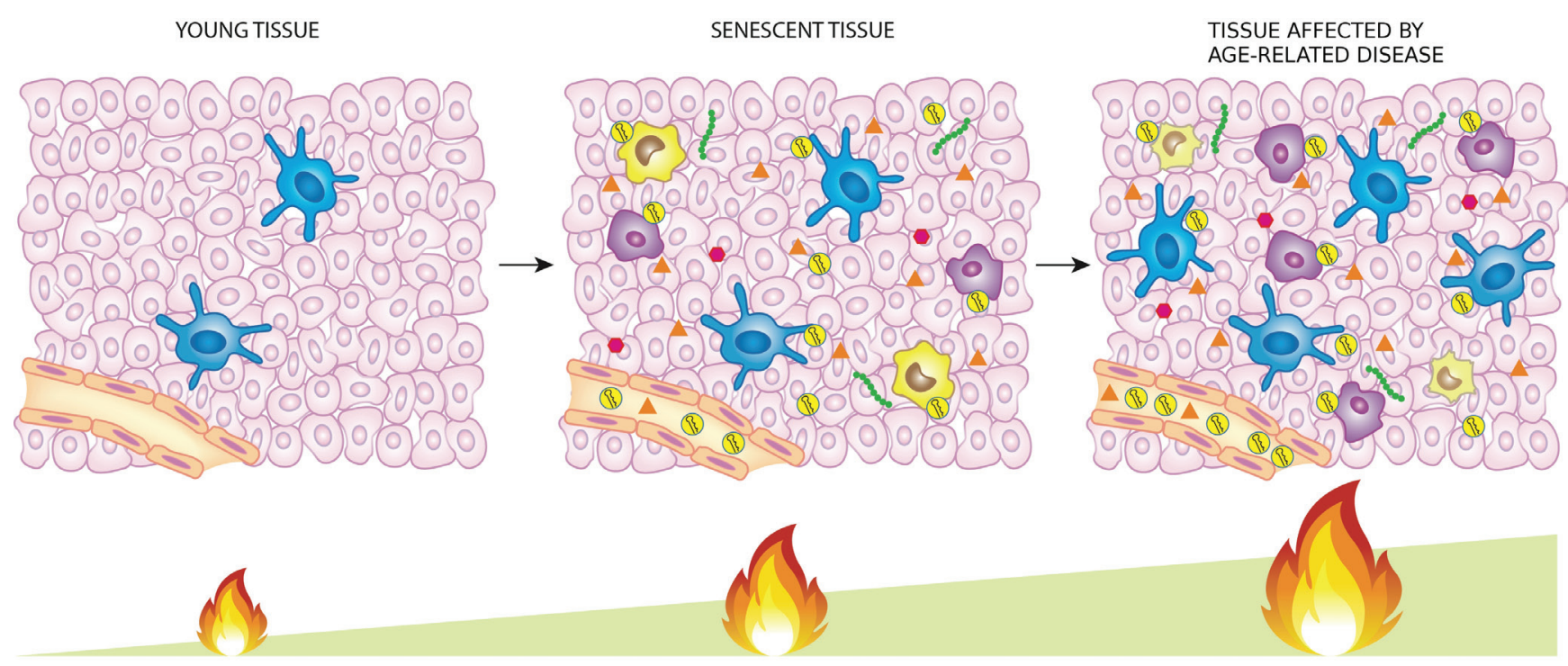

INFLAMM-AGING

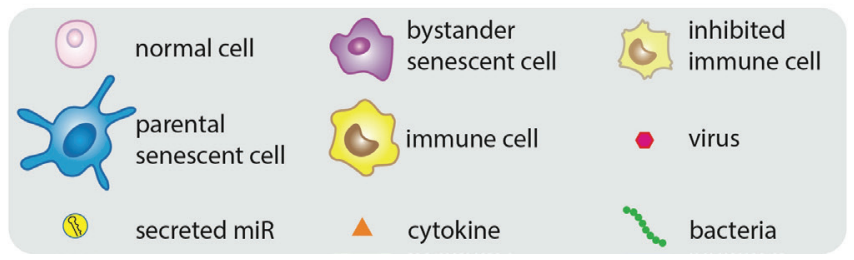

Figure 1: MiRNAs released by cells that activate the DDR/SASP may be involved in signaling to non-senescent cells, thus spreading inflamm-aging. 
responsive miRNA [59] modulated by NF-kB through binding to different domains in the gene promoter region [60]. Therefore, miR-146a is a well-established SASPmodulating miRNA [61]; it is also a key player in a negative feedback loop directed at restraining excessive synthesis and secretion of proinflammatory molecules, i.e. cytokines, chemokines, and other proinflammatory molecules, ensuring a balanced NF-kB expression in cells under different conditions [62]. Notably, its involvement in the control of macrophage activation and polarization, both in human and in animal models reinforces the notion that it is one of the master modulators of the systemic inflammatory status [63]. MiR-146a is an SA-miRNA: during cell senescence its intracellular expression significantly increases in endothelial cells [64], trabecular meshwork cells (HTM) [65], smooth muscle cells [66], and fibroblasts [67]. It is upregulated in macrophages from aged rats, resulting in an age-associated cell dysfunction [68], and has been shown to be significantly modulated in senescent human kidney epithelial cells as well as T cells [69].

It has been reported that cells undergoing senescence but not exhibiting a robust SASP did not show miR-146a/b upregulation, and that IL-1- $\alpha$ neutralizing antibodies abolished both miR-146a/b expression and IL-6 secretion [70]. It is not surprising that plasma miR-146a levels are modulated in patients with a number of ARDs, such as type 2 diabetes [71, 72], rheumatoid arthritis [73], some cancers [74], and Alzheimer's disease [75]. Despite these considerations, the association between miR-146a and human diseases is extremely complex. Since miR-146a participates in a negative feedback loop mainly aimed to curb inflammation, dynamic changes in its expression are expected in tissues with different degrees of inflammation. A strong confirmation that miR-146a is involved in the modulation of inflamm-aging and ARD development has come from animal models: knockout of the miR-146a gene in mice leads to malignancies [76], and miR-146adeficient mice develop low-grade, chronic, systemic inflammation [77].

The role of miR-146a has also been investigated in relation to the modulation of the immune response to bacteria and viruses. MiR-146, as well as miR-155 and miR-21, are commonly affected during bacterial infection, like Mycobacterium tuberculosis infection, and contribute to the immune response $[78,79]$. Notably, miR-146 and miR-155 are co-induced in many cell types in response to microbial lipopolysaccharides (LPSs) to feedbackrepress LPS signaling through Toll-like receptor (TLR) 4 [80]. MiR-146a expression is also modulated during viral infections. Elevated miR-146a expression impairs the expression pattern of interferon (IFN)- $\beta$ by targeting TRAF6 in human monocytes infected with Dengue virus [81]. Similarly, vesicular stomatitis virus (VSV) has been found to modulate miR-146a expression and to impair IFN production, inhibiting the innate antiviral immune response [82]. The exploitation of cellular miR$146 \mathrm{a}$ by Chikungunya virus (CHIKV) is involved in the modulation of the host antiviral immune response [83]. In addition, it has been reported that miR-146a upregulation by Japanese encephalitis virus (JEV) leads to suppression of NF-kB activity and disruption of antiviral Jak-STAT signaling, which helps the virus evade the cellular immune response [84]. Hepatitis B virus (HBV) promotes miR146a expression through the NF-kB signaling pathway, and miR-146a upregulation reduces the expression of an important negative regulator of the complement alternative pathway, promoting liver inflammation [85].

All these data suggest that chronic miR-146a overexpression could curb inflammation in aseptic conditions, as in accumulation of senescent cells in tissues, whereas in presence of bacterial or viral infection its upregulation may favor pathogen survival, contributing to the immunodeficiency (immunosenescence) associated with aging.

\section{miR-155}

MiR-155 also shares the features of DDR/ SASP-related miRNAs. Its expression in macrophages increases in response to LPS, TNF- $\alpha$, and IFN- $\beta$ [86]. Its serum levels have a diagnostic role in patients with a variety of carcinomas [87]. MiR-155 upregulation has been described in bone marrow-derived dendritic cells (BMDCs) under activating conditions [88]. Moreover, in human endothelial cells (HUVECs) it regulates the expression of several inflammatory molecules, attenuating the adhesion of Jurkat $\mathrm{T}$ cells to activated HUVECs and reducing HUVEC migration [89]. In addition, miR155 can inhibit IR-induced senescence both by acting downstream of the p53 and p38 mitogen-activated protein kinase (MAPK) pathways and by regulating tumor protein 53-induced nuclear protein 1 (TP53INP1) expression [90].

Notably, the recent report of a role for it as a key regulator of telomere stability has led to its inclusion among "telo-miRNAs" [91]. Surprisingly, miR-155 upregulation antagonizes telomere integrity and increases genomic instability. This finding suggests that miRNAs may have opposite effects on senescence, promoting or protecting from cell senescence based on the differential expression of their target in receiving cells: in cells involved in the inflammatory response miR-155 seems to have beneficial effects by targeting pathways that participate in the modulation of inflammation, whereas in those not directly involved in inflammation it may promote genomic instability and cell senescence, thus contributing to accelerating aging and ARD development.

Furthermore, miR-155 modulates the response to a number of bacterial infections. Following mycobacterium tuberculosis infection, miR-155-deficient mice died significantly earlier than wild-type mice [92]. MiR155 , miR-146b, and their predicted target gene IL6, are upregulated in Helicobacter pylori-positive 
gastroduodenal ulcer [93]. MiR-155 also modulates viral infections, such as HBV replication [94]. Notably, some viral miRNAs share seed sequence homology with human miR-155 [95, 96]. Both miR-155 and virus-encoded miR-155 orthologs regulate the expression of TLR3, a TLR family member that recognizes double-stranded RNA carried by some viruses such as retroviruses. Upon recognition, TLR3 induces INF production, which signals other cells to increase their antiviral defenses [97].

Unexpectedly, miR-155-deficient mice are resistant to autoimmune diseases [98, 99]. Upon stimulation with ATP, miR-155/- dendritic cells showed limited Th2 priming capacity and reduced chemotaxis and IL-1 $\beta$ secretion [100].

Notably, increased miR-155 expression levels have recently been detected in human adipocytes and macrophages and in their supernatants under LPS stimulation, providing one of the first demonstrations that miR-155 is a component of the secretome involved in the modulation of inflammation [101].

On the whole, these data show a complex interplay between miR-155 and immunity, suggesting that this miRNA may have different functions in innate and adaptive immune responses and that the systemic diffusion of this DDR/SASP-related miRNA may have both adverse and beneficial effects, depending on overall senescence/ immunological host condition.

\section{MiR-21}

MiR-21 is another DDR/SASP-related miRNA candidate. Its function is especially complex, since demonstration of its aberrant expression in numerous cancers has led to its designation as an 'onco-miR'; nonetheless it has also been shown as a key modulator in many inflammatory pathways [102, 103]. MiR21 targets two important factors in the TLR signaling pathway, myeloid differentiation factor 88 (MyD88) and interleukin-1 receptor-associated kinase 1 (IRAK1). Its upregulation reduces replicative lifespan, while stable knock-down extends the replicative life span of normal endothelial cells [104]. A mathematical model integrating miR-21 and miR-146 expression into a signaling pathway in an in silico inflammation model has shown that the negative feedback provided by miR-21 stimulates the propensity of oscillations in NF- $\mathrm{BB}$ and IL-6 activity, whereas the negative feedback provided by miR-146a dampens them [105]. This process is fairly sensitive to the inputs of miR-21 and miR-146, suggesting that variations in the relative strength of the two feedbacks may provide for altered response dynamics to the same stimulus. The model may be applied to other inflamma-miR combinations. As expected for a putative DDR/SASPrelated miRNA, miR-21 is upregulated during hepatitis $\mathrm{C}$ virus infection and negatively regulates IFN- $\alpha$ signaling through MyD88 and IRAK1; it may thus be a potential therapeutic target for antiviral intervention [106, 107].

\section{Systemic miRNAs: a word about their shuttles}

MiRNAs are released into the bloodstream inside vesicles, such as exosomes, microparticles and apoptotic bodies [108, 109], bound to HDL/LDL [110] or to RNAbinding proteins such as Argonaute 2 (Ago2) [111, 112].

Interestingly, views on the main miRNA shuttle strategies are discordant $[113,114]$. Moreover, no data have been reported on the age-related prevalence of specific miRNAs and their shuttles. All miRNA transport strategies described to date allow communication between cells found in different organs. Exosomes may be the simplest and most robust way to realize a systemic miRNA-based signal network [115]. However, little is known of how miRNA species are sorted into exosomes and what miRNA binding proteins are involved.

Exosomes and microparticles released by irradiated cells have been demonstrated to reproduce the IR bystander effect [116], suggesting that DDR activation is capable of local and systemic signal diffusion and that miRNAs and their carriers may play a crucial role in it. An increased release of exosome-like microvesicles has been detected in normal human fibroblasts during replicative senescence or premature senescence [117]. Consistent with this finding, ceramide triggers exosome secretion, and endogenous ceramide levels increase with senescence onset [118, 119]. Moreover, treatment of young human endothelial cells with exogenous ceramide induces a senescent phenotype characterized by inhibition of cell proliferation and by a concomitant rise of SA- $\beta$ gal activity [120]. The increased ceramide biosynthesis seen during cellular senescence could thus contribute to increased exosome release demonstrated in senescent cells.

HDL is another well-established circulating miR carrier, shuttling the potent gene regulators to distant tissues. The report that miRNAs carried by HDL may be altered in disease states had further broadened our understanding of the complex effects that the lipoprotein can exert on target cells and tissues [121]. The delivery of lipid-associated miRNAs to recipient cells is achieved by various routes, including endocytotic uptake, membrane fusion, and scavenger receptors [122, 123].

It is reasonable to assume that a subset of miRNAs, released by senescent cells, infected cells or directly by pathogens (like viruses and bacteria) into the tissues and/ or in the circulation inside exosomes or associated with HDL or binding proteins, may contribute to the systemic spread of DDR/SASP during aging modulating in turn both immunosenescence and inflamm-aging (Figure 1).

\section{miRNAs and their shuttles: servants of two masters}

As noted above, bacterial and viral infections alter the endogenous miRNome and try to harness it to facilitate 
virus survival and replication in the host [124, 125]. A core temporal response to infection, shared across bacteria, has recently been described; it comprises a set of miRNAs, including miR-155, that may play an essential role in the regulation of basic cellular responses to stress [126]. Notably, DNA viruses encode viral miRNA, which can interfere with many cellular activities [127, 128, 129]. A relevant example is miR-155-like encoded by Kaposi sarcoma (KS) virus [95]. Moreover, viruses exploit exosomes to silence viral genes in latently infected cells, suggesting that the virus has evolved mechanisms that curtail rather than foster the spread of infection under certain conditions [128]. However, in some conditions exosomes released by infected cells may propagate the infection by evading the immune surveillance, primarily NK activation [127, 129]. Intriguingly, virus-promoted exosome biogenesis can also stimulate the immune system, eventually resulting in chronic stimulation promoting inflamm-aging- [130]. Notably, miR-21 and miR-146a seemed to be preferentially incorporated into exosomes and were virtually undetectable as free miRNAs in the supernatant of cells infected with Kaposi sarcomaassociated herpesvirus (KSHV) [131]. Transfer of the oncogenic exosomes to immortalized endothelial cells enhanced cell migration and IL-6 secretion, suggesting that $\mathrm{KS}$-derived exosomes may be part of the paracrine signaling mechanism that mediates KSHV pathogenesis [131].

\section{Emerging role of miRNAs and their shuttles in ARDs}

MiR-21, miR-146a, and miR-155 are among the miRNAs being reported as biomarkers for a number of distinct human diseases, suggesting that they are involved in the modulation of non-specific pathogenic mechanisms [132]. The expression levels of these miRNAs are significantly modulated in senescent cells compared with younger ones as well as in plasma/serum of aged healthy subjects compared with patients with the most common ARDs [133-139]. SA-miRs and inflammamiRs are modulated during normal aging, both in cells and biological fluids, and show differential expression in a number of ARDs, such as cardiovascular diseases, T2DM, autoimmune diseases, and cancers [140]. These findings support the emerging concept that senescent cells and their secretome have a broad biological significance in human physiological aging and in ARDs [141]. Indeed, specific targeting of senescent cells in different tissues has
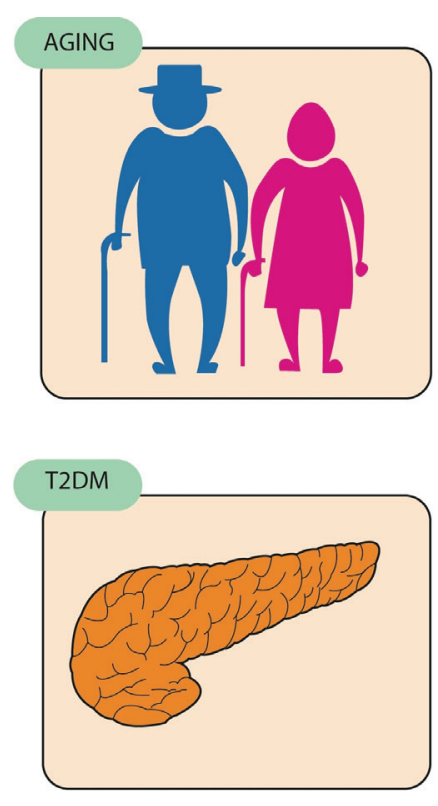
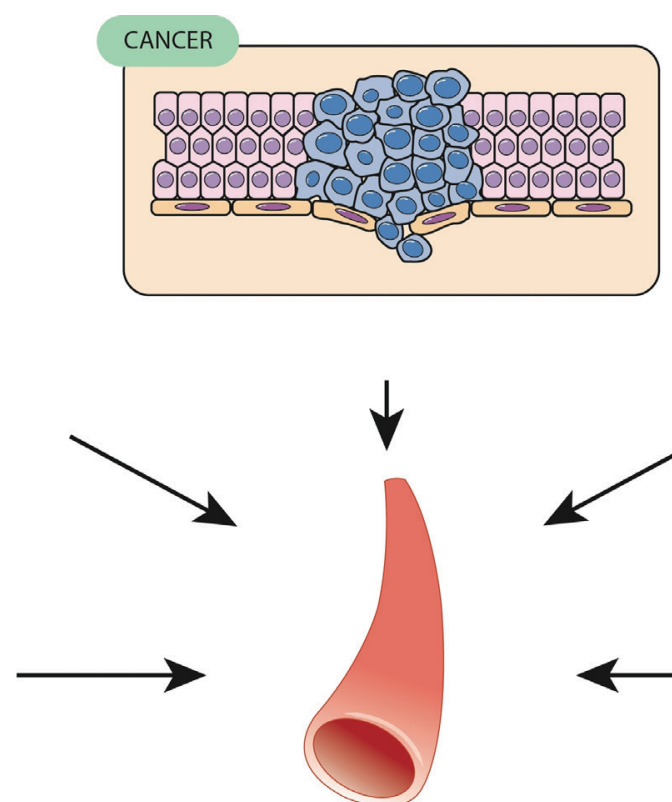
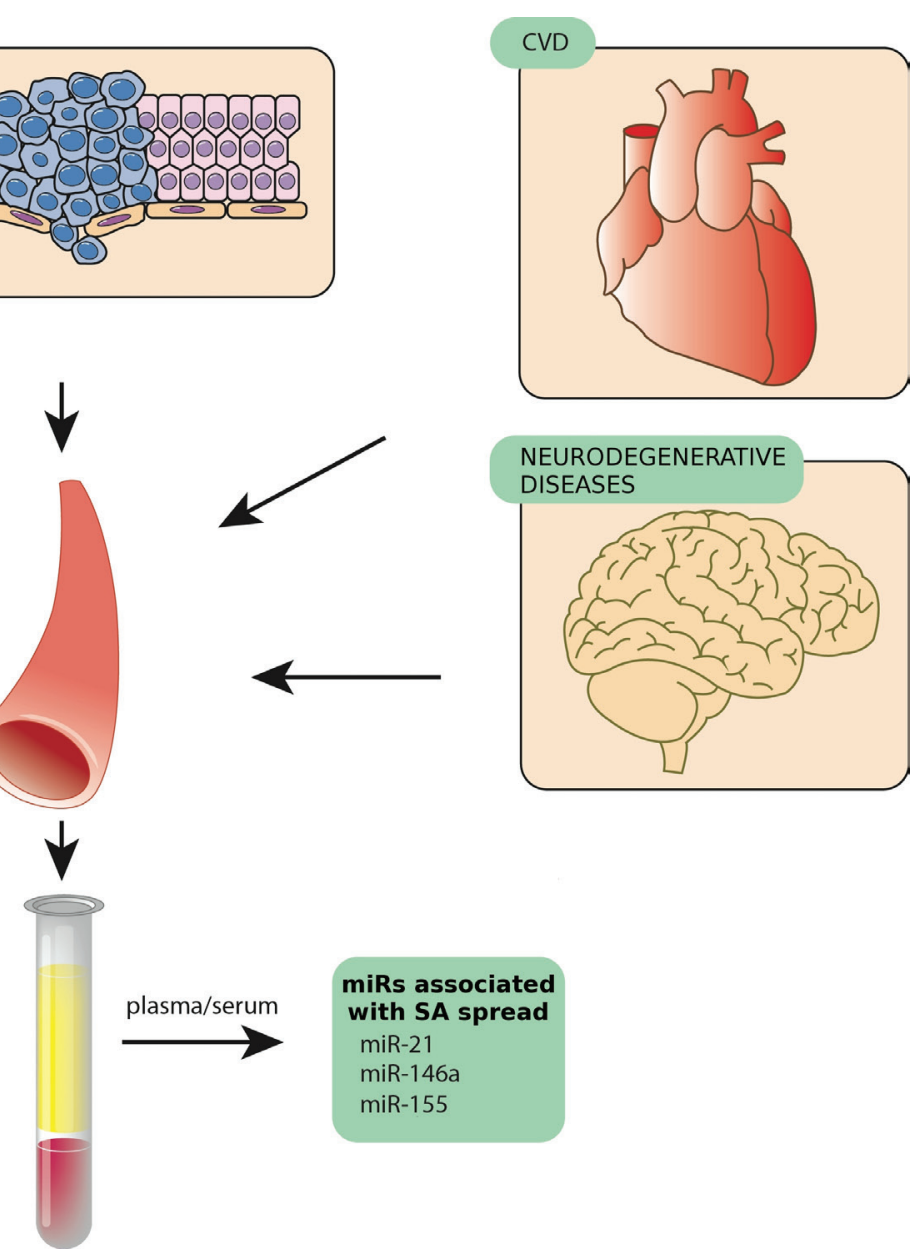

Figure 2: MiR-146, miR-155, and miR-21, three examples of circulating miRNAs released by different tissues in pathological conditions such as age-related diseases. 
been demonstrated to delay ARD development, reducing chronic inflammation through SASP modulation and probably enhancing the appropriate immunomediated responses to pathogens [142]. Since an increasing number of studies have identified miRNAs associated with cellular aging and tissue degeneration [143-147], the miRNAs involved in inflammatory process and senescence control seem to be those best matching the "identikit" of DDR/ SASP-related miRNAs that contribute to inflamm-aging (Figure 2).

\section{CONCLUSIONS}

We have discussed the hypothesis that some miRNAs play a central role in DNA damage-related cell senescence and inflammaging. It is conceivable that miRNAs released by DDR/SASP-activating cells also signal to non-senescent cells, spreading and increasing inflamm-aging. A number of studies show that both senescent and infected cells can enact miRNA-based strategies to curb their own proinflammatory status. However, the contribution of senescent cells to release of the miRNAs involved in the modulation of systemic inflammation is not well explored; in particular, it is unclear whether changes in intracellular miRNA expression patterns during senescence are paralleled by changes in the patterns of released miRNAs. Nevertheless, it is conceivable that when senescent cells with an activated DDR/SASP exceed a given threshold, changes in the network of shuttle-associated miRNAs released in the bloodstream do ensue. Current evidence suggests that miRNAs may exert opposite effects, both promoting and protecting from cell senescence. The paradox may only be apparent, because miRNAs released by senescent cells may protect them from inflammation, but promote senescence in younger cells by targeting different mRNAs from those belonging to the inflammatory pathway.

Since miRNAs released in exosomes seem to be those with the greatest ability to interconnect cells in an endocrine manner, it can be hypothesized that miRNAs contained in exosomes are subject to senescenceassociated modulation.

Identification of the profile of DDR/SASP-related miRNAs and their shuttles is expected to help clarify the intricate relationship between inflammation and immune surveillance in aging, and to lead to new therapeutic strategies that can reduce the risk of ARDs and delay their onset.

\section{ACKNOWLEDGMENTS}

The authors are grateful to Word Designs for the language revision (www.silviamodena.com).

\section{FUNDING}

This work was supported by grants from Grande Oriente d'Italia (GOI), Massoneria Italiana, Collegio delle Marche, Italy, and by grants from the "Università Politecnica delle Marche" to ADP and FO.

\section{CONFLICTS OF INTERESTS}

The authors declare that they have no competing interests.

\section{REFERENCES}

1. Malaquin N, Carrier-Leclerc A, Dessureault M, Rodier F. DDR-mediated crosstalk between DNA-damaged cells and their microenvironment. Front Genet. 2015;6:94.

2. Rodier F, Campisi J. Four faces of cellular senescence. J Cell Biol 2011;192: 547-556.

3. Hubackova S, Krejcikova K, Bartek J, Hodny Z. IL1and TGF $\beta$-Nox4 signaling, oxidative stress and DNA damage response are shared features of replicative, oncogene-induced, and drug-induced paracrine 'bystander senescence'. Aging (Albany NY) 2012;4:932-51.

4. Tominaga $\mathrm{K}$. The emerging role of senescent cells in tissue homeostasis and pathophysiology. Pathobiol Aging Age Relat Dis. 2015;5:27743.

5. Chien Y, Scuoppo C, Wang X, Fang X, Balgley B, Bolden JE, Premsrirut P, Luo W, Chicas A, Lee CS, Kogan SC, Lowe SW. Control of the senescence-associated secretory phenotype by NF- $\kappa \mathrm{B}$ promotes senescence and enhances chemosensitivity. Genes Dev 2011;25: 2125-2136.

6. Salminen A, Kauppinen A, Kaarniranta K. Emerging role of $\mathrm{NF}-\kappa \mathrm{B}$ signaling in the induction of senescence-associated secretory phenotype (SASP). Cell Signal 2012; 24: 835845 .

7. Acosta JC, Banito A, Wuestefeld T, Georgilis A, Janich P, Morton JP, Athineos D, Kang TW, Lasitschka F, Andrulis M, Pascual G, Morris KJ, Khan S, Jin H, Dharmalingam G, Snijders AP, Carroll T, Capper D, Pritchard C, Inman GJ, Longerich T, Sansom OJ, Benitah SA, Zender L, Gil J. A complex secretory program orchestrated by the inflammasome controls paracrine senescence. Nat Cell Biol 2013; 15: 978-990.

8. Qiao Y, Wang P, Qi J, Zhang L, Gao C. TLR-induced $\mathrm{NF}-\kappa \mathrm{B}$ activation regulates NLRP3 expression in murine macrophages. FEBS Lett. 2012;586:1022-6.

9. Studebaker AW, Storci G, Werbeck JL, Sansone P, Sasser AK, Tavolari S, Huang T, Chan MW, Marini FC, Rosol TJ, Bonafé M, Hall BM. Fibroblasts isolated from common sites of breast cancer metastasis enhance cancer cell growth rates and invasiveness in an interleukin-6-dependent manner. Cancer Res 2008;68:9087-95.

10. Orjalo AV, Bhaumik D, Gengler BK, Scott GK, Campisi 
J. Cell surface-bound IL-1alpha is an upstream regulator of the senescence-associated IL-6/IL-8 cytokine network. Proc Natl Acad Sci U S A 2009; 106: 17031-1706.

11. Kuilman T, Michaloglou C, Vredeveld LC, Douma S, van Doorn R, Desmet CJ, Aarden LA, Mooi WJ, Peeper DS. Oncogene-induced senescence relayed by an interleukindependent inflammatory network. Cell 2008; 133: 10191031.

12. Nelson G, Wordsworth J, Wang C, Jurk D, Lawless C, Martin-Ruiz C, von Zglinicki T. A senescent cell bystander effect: senescence-induced senescence. Aging Cell 2012; 11: 345-349.

13. Campisi J, d'Adda di Fagagna F. Cellular senescence: when bad things happen to good cells. Nat Rev Mol Cell Biol 2007; 8: 729-740.

14. Pérez-Mancera PA, Young AR, Narita M. Inside and out: the activities of senescence in cancer. Nat Rev Cancer 2014;14: 547-558.

15. Baker DJ, Wijshake $\mathrm{T}$, Tchkonia $\mathrm{T}$, LeBrasseur NK, Childs BG, van de Sluis B, Kirkland JL, van Deursen JM. Clearance of p16Ink4a-positive senescent cells delays ageing-associated disorders. Nature 2011;479: 232-236.

16. Zhu Y, Tchkonia T, Pirtskhalava T, Gower A, Ding H, Giorgadze N, Palmer AK, Ikeno Y, Borden G, Lenburg M, O'Hara SP, LaRusso NF, Miller JD, et al. The Achilles' Heel of Senescent Cells: From Transcriptome to Senolytic Drugs. Aging Cell. 2015.

17. Minamino T, Miyauchi H, Yoshida T, Ishida Y, Yoshida $\mathrm{H}$, Komuro I. Endothelial cell senescence in human atherosclerosis: role of telomere in endothelial dysfunction. Circulation 2002;105:1541-1544.

18. Bhat R, Crowe EP, Bitto A, Moh M, Katsetos CD, Garcia FU, Johnson FB, Trojanowski JQ, Sell C, Torres C. Astrocyte senescence as a component of Alzheimer's disease. PLoS One. 2012;7:e45069. doi: 10.1371/journal. pone.0045069.

19. Schmitt R, Susnik N, Melk A. Molecular aspects of renal senescence. Curr Opin Organ Transplant. 2015;20:412-416. doi: 10.1097/MOT.0000000000000214

20. Waaijer ME, Parish WE, Strongitharm BH, van Heemst D, Slagboom PE, de Craen AJ, Sedivy JM, Westendorp RG, Gunn DA, Maier AB. The number of $\mathrm{p} 16 \mathrm{INK} 4 \mathrm{a}$ positive cells in human skin reflects biological age. Aging Cell. 2012;11:722-5. doi: 10.1111/j.1474-9726.2012.00837.x.

21. White RR, Milholland B, de Bruin A, Curran S, Laberge RM, van Steeg H, Campisi J, Maslov AY, Vijg J. Controlled induction of DNA double-strand breaks in the mouse liver induces features of tissue ageing. Nat Commun. 2015;6:6790. doi: 10.1038/ncomms7790.

22. Coppé JP, Desprez PY, Krtolica A, Campisi J. The senescence-associated secretory phenotype: the dark side of tumor suppression. Annu Rev Pathol. 2010;5:99-118.

23. Purcell M, Kruger A, Tainsky MA. Gene expression profiling of replicative and induced senescence. Cell Cycle
2014; 13:3927-37.

24. Burton DG, Faragher RG. Cellular senescence: from growth arrest to immunogenic conversion. Age (Dordr). 2015;37:27. doi: 10.1007/s11357-015-9764-2.

25. Nelson G, von Zglinicki T. Monitoring DNA damage during cell senescence. Methods Mol Biol. 2013;965:197213.

26. Sagiv A, Krizhanovsky V. Immunosurveillance of senescent cells: the bright side of the senescence program. Biogerontology 2013;14: 617-628.

27. Neves J, Demaria M, Campisi J, Jasper H. Of Flies, Mice, and Men: Evolutionarily Conserved Tissue Damage Responses and Aging. Dev Cell. 2015;32:9-18.

28. Childs BG, Baker DJ, Kirkland JL, Campisi J, van Deursen JM. Senescence and apoptosis: dueling or complementary cell fates? EMBO Rep 2014;15: 1139-1153.

29. Demaria M, Ohtani N, Youssef SA, Rodier F, Toussaint W, Mitchell JR, Laberge RM, Vijg J, Van Steeg H, Dollé ME, Hoeijmakers JH, de Bruin A, Hara E, Campisi J. An Essential Role for Senescent Cells in Optimal Wound Healing through Secretion of PDGF-AA. Dev Cell. 2014;31:722-33.

30. Nelson G, Wordsworth J, Wang C, Jurk D, Lawless C, Martin-Ruiz C, von Zglinicki T. A senescent cell bystander effect: senescence-induced senescence. Aging Cell. 2012;11:345-9.

31. Sokolov MV, Dickey JS, Bonner WM, Sedelnikova OA. gamma-H2AX in bystander cells: not just a radiationtriggered event, a cellular response to stress mediated by intercellular communication. Cell Cycle. 2007;6:2210-2.

32. Mothersill C, Seymour CB. Radiation-induced bystander effects and the DNA paradigm: an "out of field" perspective. Mutat Res. 2006;597:5-10.

33. Mukherjee D, Coates PJ, Lorimore SA, Wright EG. Responses to ionizing radiation mediated by inflammatory mechanisms. J Pathol 2014;232:289-299.

34. Hellweg CE. The Nuclear Factor $\kappa \mathrm{B}$ pathway: A link to the immune system in the radiation response. Cancer Lett. 2015; 368:275-89.

35. Poleszczuk J, Krzywon A, Forys U, Widel M. Connecting Radiation-Induced Bystander Effects and Senescence to Improve Radiation Response Prediction. Radiat Res. 2015; 183:571-7

36. Zhu Y, Armstrong JL, Tchkonia T, Kirkland JL. Cellular senescence and the senescent secretory phenotype in agerelated chronic diseases. Curr Opin Clin Nutr Metab Care. 2014; 17:324-8.

37. Xiaofei and Kowalik Viruses 2014, 6, 2155-2185.

38. Savva GM, Pachnio A, Kaul B, Morgan K, Huppert FA, Brayne C, Moss PA; Medical Research Council Cognitive Function and Ageing Study. Cytomegalovirus infection is associated with increased mortality in the older population. Aging Cell. 2013;12:381-7.

39. Hollingworth R1, Grand RJ2. Viruses. 2015 May 
22;7(5):2542-91. doi: 10.3390/v7052542. Modulation of DNA damage and repair pathways by human tumour viruses

40. McFadden K, Luftig MA. Interplay between DNA tumor viruses and the host DNA damage response. Curr Top Microbiol Immunol. 2013;371:229-57.

41. Wylie KM, Mihindukulasuriya KA, Zhou Y, Sodergren E, Storch GA, Weinstock GM Metagenomic analysis of double-stranded DNA viruses in healthy adults. BMC Biol. 2014;12:71.

42. Foulongne V, Sauvage V, Hebert C, Dereure O, Cheval J, Gouilh MA, Pariente K, Segondy M, Burguière A, Manuguerra JC, Caro V, Eloit M.Human skin microbiota: high diversity of DNA viruses identified on the human skin by high throughput sequencing. PLoS One. 2012;7:e38499.

43. Dinakaran V, Rathinavel A, Pushpanathan M, Sivakumar R, Gunasekaran P, Rajendhran J. Elevated levels of circulating DNA in cardiovascular disease patients: metagenomic profiling of microbiome in the circulation. PLoS One. 2014;9:e105221.

44. Santiago-Rodriguez TM, Ly M, Bonilla N, Pride DT. The human urine virome in association with urinary tract infections. Front Microbiol. 2015;6:14.

45. Popgeorgiev N, Temmam S, Raoult D, Desnues C.Describing the silent human virome with an emphasis on giant viruses. Intervirology 2013;56:395-412.

46. Young JC, Chehoud C, Bittinger K, Bailey A, Diamond JM, Cantu E, Haas AR, Abbas A, Frye L, Christie JD, Bushman FD, Collman RG. Viral metagenomics reveal blooms of anelloviruses in the respiratory tract of lung transplant recipients. Am J Transplant. 2015;15:200-9.

47. De Vlaminck I, Khush KK, Strehl C, Kohli B, Luikart H, Neff NF, Okamoto J, Snyder TM, Cornfield DN, Nicolls MR, Weill D, Bernstein D, Valantine HA, Quake SR. Temporal response of the human virome to immunosuppression and antiviral therapy. Cell. 2013 Nov 21;155(5):1178-87. doi: 10.1016/j.cell.2013.10.034

48. Kutikhin AG1, Yuzhalin AE2, Brusina EB3Mimiviridae, Marseilleviridae, and virophages as emerging human pathogens causing healthcare-associated infections. GMS Hyg Infect Control. 2014 Aug 19;9(2):Doc16. doi: 10.3205/ dgkh000236. eCollection 2014.

49. Duerkop BA, Hooper LV.Resident viruses and their interactions with the immune system. Nat Immunol. 2013 Jul;14(7):654-9. doi: 10.1038/ni.2614

50. Virgin HW.The virome in mammalian physiology and disease. Cell. 2014;157:142-50.

51. Franceschi C, Bonafè M, Valensin S.Human immunosenescence: the prevailing of innate immunity, the failing of clonotypic immunity, and the filling of immunological space. Vaccine. 2000 Feb 25;18(16):171720. Review

52. Abdelmohsen K, Srikantan S, Kang MJ, Gorospe M. Regulation of senescence by microRNA biogenesis factors.
Ageing Res Rev. 2012; 11:491-500.

53. Abend JR, Ramalingam D, Kieffer-Kwon P, Uldrick TS, Yarchoan R, Ziegelbauer JM. Kaposi's sarcoma-associated herpesvirus microRNAs target IRAK1 and MYD88, two components of the toll-like receptor/interleukin1R signaling cascade, to reduce inflammatory-cytokine expression. J Virol. 2012;86:11663-74.

54. Cichocki F, Felices M, McCullar V, Presnell SR, Al-Attar A, Lutz CT, Miller JS. Cutting edge: microRNA-181 promotes human NK cell development by regulating Notch signaling. J Immunol. 2011;187:6171-5.

55. Beaulieu AM, Bezman NA, Lee JE, Matloubian M, Sun JC, Lanier LL. MicroRNA function in NK-cell biology. Immunol Rev. 2013;253:40-52.

56. Leong JW, Sullivan RP, Fehniger TA. microRNA management of NK-cell developmental and functional programs. Eur J Immunol. 2014;44:2862-8.

57. Burocchi A, Pittoni P, Tili E, Rigoni A, Costinean S, Croce CM, Colombo MP. Regulated Expression of miR-155 is Required for iNKT Cell Development. Front Immunol. 2015;6:140.

58. Saba R, Sorensen DL, Booth SA. MicroRNA-146a: A Dominant, Negative Regulator of the Innate Immune Response. Front Immunol. 2014;5:578.

59. Perry MM, Williams AE, Tsitsiou E, Larner-Svensson HM, Lindsay MA. Divergent intracellular pathways regulate interleukin-1beta-induced miR-146a and miR$146 \mathrm{~b}$ expression and chemokine release in human alveolar epithelial cells. FEBS Lett. 2009;583:3349-55.

60. Ma X, Becker Buscaglia LE, Barker JR, Li Y. MicroRNAs in NF-kappaB signaling. J Mol Cell Biol. 2011;3:159-66.

61. Freund A, Orjalo AV, Desprez PY, Campisi J. Inflammatory networks during cellular senescence: causes and consequences. Trends Mol Med. 2010;16:238-46.

62. Bhaumik D, Scott GK, Schokrpur S, Patil CK, Orjalo AV, Rodier F, Lithgow GJ, Campisi J. MicroRNAs miR$146 \mathrm{a} / \mathrm{b}$ negatively modulate the senescence-associated inflammatory mediators IL-6 and IL-8. Aging (Albany NY) 2009; 1: 402-411.

63. Vergadi E, Vaporidi K, Theodorakis EE, Doxaki C, Lagoudaki E, Ieronymaki E, Alexaki VI, Helms M, Kondili E, Soennichsen B, Stathopoulos EN, Margioris AN, Georgopoulos D, Tsatsanis C. Akt2 Deficiency Protects from Acute Lung Injury via Alternative Macrophage Activation and miR-146a Induction in Mice. J Immunol. 2014; 192:394-406.

64. Olivieri F, Lazzarini R, Recchioni R, Marcheselli F, Rippo MR, Di Nuzzo S, Albertini MC, Graciotti L, Babini L, Mariotti S, Spada G, Abbatecola AM, Antonicelli R, Franceschi C, Procopio AD. MiR-146a as marker of senescence-associated pro-inflammatory status in cells involved in vascular remodelling. Age (Dordr). 2013;35:1157-72.

65. Li G, Luna C, Qiu J, Epstein DL, Gonzalez P. Modulation 
of inflammatory markers by miR-146a during replicative senescence in trabecular meshwork cells. Invest Ophthalmol Vis Sci. 2010;51:2976-85.

66. Comer BS, Camoretti-Mercado B, Kogut PC, Halayko AJ, Solway J, Gerthoffer WT. MicroRNA-146a and microRNA-146b expression and anti-inflammatory function in human airway smooth muscle. Am J Physiol Lung Cell Mol Physiol. 2014;307:L727-34.

67. Bonifacio LN, Jarstfer MB. MiRNA profile associated with replicative senescence, extended cell culture, and ectopic telomerase expression in human foreskin fibroblasts. PLoS One. 2010;5: e12519.

68. Jiang M, Xiang Y, Wang D, Gao J, Liu D, Liu Y, Liu S, Zheng D. Dysregulated expression of miR-146a contributes to age-related dysfunction of macrophages. Aging Cell 2012;11: 29-40.

69. Hackl M, Brunner S, Fortschegger K, Schreiner C, Micutkova L, Mück C, Laschober GT, Lepperdinger G, Sampson N, Berger P, Herndler-Brandstetter D, Wieser M, Kühnel H, et al. miR-17, miR-19b, miR-20a, and miR$106 \mathrm{a}$ are down-regulated in human aging. Aging Cell. 2010;9:291-296. doi: 10.1111/j.1474-9726.2010.00549.x.

70. Bhaumik D, Scott GK, Schokrpur S, Patil CK, Orjalo AV, Rodier F, Lithgow GJ, Campisi J. MicroRNAs miR$146 \mathrm{a} / \mathrm{b}$ negatively modulate the senescence-associated inflammatory mediators IL-6 and IL-8. Aging (Albany NY) 2009; 1: 402-411.

71. Rong Y, Bao W, Shan Z, Liu J, Yu X, Xia S, Gao H, Wang X, Yao P, Hu FB, Liu L. Increased microRNA-146a levels in plasma of patients with newly diagnosed type 2 diabetes mellitus. PLoS One 2013; 8: e73272.

72. Baldeón R L, Weigelt K, de Wit H, Ozcan B, van Oudenaren A, Sempértegui F, Sijbrands E, Grosse L, Freire W, Drexhage HA, Leenen PJ. Decreased serum level of miR-146a as sign of chronic inflammation in type 2 diabetic patients. PLoS One. 2014;9:e115209.

73. Mookherjee N, El-Gabalawy HS. High degree of correlation between whole blood and PBMC expression levels of miR155 and miR-146a in healthy controls and rheumatoid arthritis patients. J Immunol Methods 2013;400-401:10610.

74. Kumar S, Keerthana R, Pazhanimuthu A, Perumal P. Overexpression of circulating miRNA-21 and miRNA$146 \mathrm{a}$ in plasma samples of breast cancer patients. Indian $\mathrm{J}$ Biochem Biophys 2013; 50: 210-214.

75. Kiko T, Nakagawa K, Tsuduki T, Furukawa K, Arai H, Miyazawa T. MicroRNAs in Plasma and Cerebrospinal Fluid as Potential Markers for Alzheimer's Disease. J Alzheimers Dis 2014;39:253-9.

76. Zhao JL, Rao DS, Boldin MP, Taganov KD, O'Connell RM, Baltimore D. NF-kappaB dysregulation in microRNA146a-deficient mice drives the development of myeloid malignancies. Proc Natl Acad Sci U S A. 2011;108:9184-9.

77. Boldin MP, Taganov KD, Rao DS, Yang L, Zhao JL,
Kalwani M, Garcia-Flores Y, Luong M, Devrekanli A, Xu J, Sun G, Tay J, Linsley PS, Baltimore D. MiR-146a is a significant brake on autoimmunity, myeloproliferation, and cancer in mice. J Exp Med. 2011;208:1189-201.

78. Staedel C, Darfeuille F. MicroRNAs and bacterial infection. Cell Microbiol. 2013;15:1496-507.

79. Liu Z, Zhou G, Deng X, Yu Q, Hu Y, Sun H, Wang Z, Chen $\mathrm{H}$, Jia C, Wang D. Analysis of miRNA expression profiling in human macrophages responding to Mycobacterium infection: induction of the immune regulator miR-146a. J Infect. 2014;68:553-61.

80. Schulte LN, Westermann AJ, Vogel J. Differential activation and functional specialization of miR-146 and miR-155 in innate immune sensing. Nucleic Acids Res. 2013;41:542-53.

81. Wu S, He L, Li Y, Wang T, Feng L, Jiang L, Zhang P, Huang X. MiR-146a facilitates replication of dengue virus by dampening interferon induction by targeting TRAF6. J Infect 2013; 67: 329-341.

82. Hou J, Wang P, Lin L, Liu X, Ma F, An H, Wang Z, Cao X. MicroRNA-146a feedback inhibits RIG-I-dependent Type I IFN production in macrophages by targeting TRAF6, IRAK1, and IRAK2. J Immunol 2009; 183: 2150-2158.

83. Selvamani SP, Mishra R, Singh SK. Chikungunya virus exploits miR-146a to regulate NF- $\kappa \mathrm{B}$ pathway in human synovial fibroblasts. PLoS One. 2014;9:e103624.

84. Sharma N, Verma R, Kumawat KL, Basu A, Singh SK. miR-146a suppresses cellular immune response during Japanese encephalitis virus JaOArS982 strain infection in human microglial cells. J Neuroinflammation. 2015;12:30.

85. Li JF, Dai XP, Zhang W, Sun SH, Zeng Y, Zhao GY, Kou ZH, Guo Y, Yu H, Du LY, Jiang SB, Zhou YS. Upregulation of MicroRNA-146a by Hepatitis B Virus $\mathrm{X}$ Protein Contributes to Hepatitis Development by Downregulating Complement Factor H. MBio. 2015;6. pii: e02459-14.

86. Mashima R. Physiological roles of miR-155. Immunology. 2015; 145:323-33.

87. Wu C, Liu Q, Liu B. MicroRNA-155 Hallmarks Promising Accuracy for the Diagnosis of Various Carcinomas: Results from a Meta-Analysis. Dis Markers. 2015;2015:327287.

88. Park S, Kang S, Min KH, Woo Hwang K, Min H. Age-associated changes in microRNA expression in bone marrow derived dendritic cells. Immunol Invest. 2013;42:179-90.

89. Zhu N, Zhang D, Chen S, Liu X, Lin L, Huang X, Guo Z, Liu J, Wang Y, Yuan W, Qin Y. Endothelial enriched microRNAs regulate angiotensin II-induced endothelial inflammation and migration. Atherosclerosis. 2011;215:286-93.

90. Wang Y, Scheiber MN, Neumann C, Calin GA, Zhou D. MicroRNA regulation of ionizing radiation-induced premature senescence. Int $\mathrm{J}$ Radiat Oncol Biol Phys. 2011;81:839-48. 
91. Dinami R, Ercolani C, Petti E1, Piazza S, Ciani Y, Sestito R, Sacconi A, Biagioni F, le Sage C, Agami R, Benetti R, Mottolese M, Schneider C, Blandino G, Schoeftner S. miR155 drives telomere fragility in human breast cancer by targeting TRF1. Cancer Res 2014;74: 4145-56.

92. Iwai H, Funatogawa K, Matsumura K, Kato-Miyazawa M, Kirikae F, Kiga K, Sasakawa C, Miyoshi-Akiyama T, Kirikae T. MicroRNA-155 knockout mice are susceptible to Mycobacterium tuberculosis infection. Tuberculosis (Edinb). 2015; pii: S1472-9792(14)20671-8.

93. Cheng SF, Li L, Wang LM. miR-155 and miR-146b negatively regulates IL6 in Helicobacter pylori (cagA+) infected gastroduodenal ulcer. Eur Rev Med Pharmacol Sci. 2015;19:607-13

94. Sarkar N, Panigrahi R, Pal A, Biswas A, Singh SP, Kar SK, Bandopadhyay M, Das D, Saha D, Kanda T, Sugiyama M, Chakrabarti S, Banerjee A, Chakravarty R. Expression of microRNA-155 correlates positively with the expression of Toll-like receptor 7 and modulates hepatitis $\mathrm{B}$ virus via $\mathrm{C} /$ EBP- $\beta$ in hepatocytes. J Viral Hepat. 2015; 22:817-27.

95. Zhu Y, Haecker I, Yang Y, Gao SJ, Renne R. Curr Opin Virol. $\gamma$-Herpesvirus-encoded miRNAs and their roles in viral biology and pathogenesis. 2013;3:266-75

96. Chi JQ, Teng M, Yu ZH, Xu H, Su JW, Zhao P, Xing GX, Liang HD, Deng RG, Qu LH, Zhang GP, Luo J. Marek's disease virus-encoded analog of microRNA-155 activates the oncogene c-Myc by targeting LTBP1 and suppressing the TGF- $\beta$ signaling pathway. Virology. 2015;476:72-84.

97. Hu X, Ye J, Qin A, Zou H, Shao H, Qian K. Both MicroRNA-155 and Virus-Encoded MiR-155 Ortholog Regulate TLR3 Expression. PLoS One. 2015;10:e0126012.

98. Xin Q, Li J, Dang J, Bian X, Shan S, Yuan J, Qian Y, Liu Z, Liu G3, Yuan Q, Liu N, Ma X, Gao F, Gong Y, Liu Q. miR155 Deficiency Ameliorates Autoimmune Inflammation of Systemic Lupus Erythematosus by Targeting S1pr1 in Faslpr/lpr Mice. J Immunol. 2015; pii: 1403028.

99. Zhang J, Braun MY. PD-1 deletion restores susceptibility to experimental autoimmune encephalomyelitis in miR-155deficient mice. Int Immunol. 2014;26:407-15.

100. Zech A, Ayata KC, Pankratz F, Meyer A, Baudiß K, Cicko S, Yegutkin GG, Grundman S, Idzko M. MicroRNA-155 modulates P2R-signaling and Th2-priming of dendritic cells during allergic airway inflammation in mice. Allergy. 2015; 70:1121-9.

101. Ortega FJ, Moreno M, Mercader JM, Moreno-Navarrete JM, Fuentes-Batllevell N, Sabater M, Ricart W, FernándezReal JM. Inflammation triggers specific microRNA profiles in human adipocytes and macrophages and in their supernatants. Clin Epigenetics 2015;7:49.

102. Kumarswamy R, Volkmann I, Thum T. Regulation and function of miRNA-21 in health and disease. RNA Biol. 2011;8:706-13.

103. Olivieri F, Spazzafumo L, Santini G, Lazzarini R, Albertini MC, Rippo MR, Galeazzi R, Abbatecola AM, Marcheselli
F, Monti D, Ostan R, Cevenini E, Antonicelli R, Franceschi $\mathrm{C}$, Procopio AD. Age-related differences in the expression of circulating microRNAs: miR-21 as a new circulating marker of inflammaging. Mech Ageing Dev. 2012;133: 675-685.

104. Dellago H, Preschitz-Kammerhofer B, Terlecki-Zaniewicz L, Schreiner C, Fortschegger K, Chang MW, Hackl M, Monteforte R, Kühnel H, Schosserer M, Gruber F, Tschachler E, Scheideler M, Freund A, Orjalo AV, Desprez PY, Campisi J. Inflammatory networks during cellular senescence: causes and consequences. Trends Mol Med 2010;16:238-246.

105. Xue X, Xia W, Wenzhong H. A modeled dynamic regulatory network of NF- $\mathrm{BB}$ and IL- 6 mediated by miRNA. Biosystems 2013; 114:214-218.

106. Chen X, Liang H, Zhang J, Zen K, Zhang CY. microRNAs are ligands of Toll-like receptors. RNA 2013; 19: 737-739.

107. Fu YR, Liu XJ, Li XJ, Shen ZZ, Yang B, Wu CC, Li JF, Miao LF, Ye HQ, Qiao GH, Rayner S, Chavanas S, Davrinche C, Britt WJ, Tang Q, McVoy M, Mocarski E, Luo MH. MicroRNA miR-21 attenuates human cytomegalovirus replication in neural cells by targeting Cdc25a. J Virol 2015;89:1070-82.

108. Valadi H, Ekström K, Bossios A, Sjöstrand M, Lee JJ, Lötvall JO. Exosome-mediated transfer of mRNAs and microRNAs is a novel mechanism of genetic exchange between cells. Nat Cell Biol. 2007;9:654-9.

109. Zernecke A, Bidzhekov K, Noels H, Shagdarsuren E, Gan L, Denecke B, Hristov M, Köppel T, Jahantigh MN, Lutgens E, Wang S, Olson EN, Schober A, Weber C. Delivery of microRNA-126 by apoptotic bodies induces CXCL12-dependent vascular protection. Sci Signal, 2009; 2:ra81.

110. Vickers KC, Remaley AT. Lipid-based carriers of microRNAs and intercellular communication. Curr Opin Lipidol 2012;23: 91-97.

111. Arroyo JD, Chevillet JR, Kroh EM, Ruf IK, Pritchard CC, Gibson DF, Mitchell PS, Bennett CF, PogosovaAgadjanyan EL, Stirewalt DL, Tait JF, Tewari M. Argonaute2 complexes carry a population of circulating microRNAs independent of vesicles in human plasma. Proc Natl Acad Sci U S A. 2011;108:5003-8.

112. Turchinovich A, Weiz L, Langheinz A, Burwinkel B. Characterization of extracellular circulating microRNA. Nucleic Acids Res. 2011;39:7223-33.

113. Turchinovich A, Burwinkel B. Distinct AGO1 and AGO2 associated miRNA profiles in human cells and blood plasma. RNA Biol. 2012;9:1066-75.

114. Diehl P, Fricke A, Sander L, Stamm J, Bassler N, Htun N, Ziemann M, Helbing T, El-Osta A, Jowett JB, Peter K, Microparticles: major transport vehicles for distinct microRNAs in circulation. Cardiovasc Res 2012; 93: 633644.

115. Finn NA, Searles CD. Using information theory to assess 
the communicative capacity of circulating microRNA. Biochem Biophys Res Commun 2013; 440: 1-7.

116. Al-Mayah A, Bright S, Chapman K, Irons S, Luo P, Carter D, Goodwin E, Kadhim M. The non-targeted effects of radiation are perpetuated by exosomes. Mutat Res. 2015;772:38-45.

117. Lehmann BD, Paine MS, Brooks AM, McCubrey JA, Renegar RH, Wang R, Terrian DM. Senescence-associated exosome release from human prostate cancer cells. Cancer Res. 2008;68:7864-71.

118. Kosaka N, Iguchi H, Yoshioka Y, Takeshita F, Matsuki Y, Ochiya T. Secretory mechanisms and intercellular transfer of microRNAs in living cells. J Biol Chem 2010; 285: $7442-7452$.

119. Venable ME, Yin X. Ceramide induces endothelial cell senescence. Cell Biochem Funct 2009; 27: 547-551.

120. Ouimet M, Moore KJ. A big role for small RNAs in HDL homeostasis. J Lipid Res 2013;54: 1161-1167.

121. Xu J, Chen Q, Zen K, Zhang C, Zhang Q. Synaptosomes secrete and uptake functionally active microRNAs via exocytosis and endocytosis pathways. Neurochem 2013;124: 15-25.

122. Vickers KC, Remaley AT. Lipid-based carriers of microRNAs and intercellular communication. Curr Opin Lipidol. 2012;23:91-7.

123. Moens U, Rasheed K, Abdulsalam I and Sveinbjørnsson B. The Role of Merkel Cell Polyomavirus and Other Human Polyomaviruses in Emerging Hallmarks of Cancer. Viruses 2015; 7: 1871-1901.

124. Honegger A, Schilling D, Bastian S, Sponagel J, Kuryshev V, Sültmann H, Scheffner M, Hoppe-Seyler K, HoppeSeyler F. Dependence of intracellular and exosomal microRNAs on viral E6/E7 oncogene expression in HPVpositive tumor cells. PLoS Pathog. 2015;11:e1004712.

125. Siddle KJ, Tailleux L, Deschamps M, Loh YH, Deluen C, Gicquel B, Antoniewski C, Barreiro LB, Farinelli L, Quintana-Murci L. bacterial infection drives the expression dynamics of microRNAs and their isomiRs. PLoS Genet. 2015;11:e1005064.

126. Barth S, Meister G, Grässer FA. EBV-encoded miRNAs. Biochim Biophys Acta. 2011;1809:631-40.

127. Meckes DG Jr. Exosomal Communication Goes Viral. J Virol. 2015.

128. Kalamvoki M, Du T, Roizman B. Cells infected with herpes simplex virus 1 export to uninfected cells exosomes containing STING, viral mRNAs, and microRNAs. Proc Natl Acad Sci U S A. 2014;111:E4991-6.

129. Goldberger T, Mandelboim O.M. The use of microRNA by human viruses: lessons from NK cells and HCMV infection. Semin Immunopathol 2014;36:659-74.

130. Dreux M, Garaigorta U, Boyd B, Décembre E, Chung J, Whitten-Bauer C, Wieland S, Chisari FV. Short-range exosomal transfer of viral RNA from infected cells to plasmacytoid dendritic cells triggers innate immunity. Cell
Host Microbe. 2012;12:558-70.

131. Chugh PE, Sin SH, Ozgur S, Henry DH, Menezes P, Griffith J, Eron JJ, Damania B, Dittmer DP. Systemically circulating viral and tumor-derived microRNAs in KSHVassociated malignancies. PLoS Pathog. 2013;9:e1003484.

132. Haider BA, Baras AS, McCall MN, Hertel JA, Cornish TC, Halushka MK. A Critical Evaluation of microRNA Biomarkers in Non-Neoplastic Disease. PLoS One 2014; 9:e89565.

133. Olivieri F, Procopio AD, Montgomery RR. Effect of aging on microRNAs and regulation of pathogen recognition receptors. Curr Opin Immunol 2014; 29: 29-37.

134. Dimmeler S, Nicotera P, MicroRNAs in age $\square$ related diseases. EMBO Mol Med 2013;5:180-90.

135. Seeger T, Haffez F, Fischer A, Koehl U, Leistner DM, Seeger FH, Boon RA, Zeiher AM, Dimmeler S. Immunosenescence-associated microRNAs in age and heart failure. Eur J Heart Fail. 2013;15:385-93.

136. D’Alessandra Y, Carena MC, Spazzafumo L, Martinelli F, Bassetti B, Devanna P, Rubino M, Marenzi G, Colombo GI, Achilli F, Maggiolini S, Capogrossi MC, Pompilio G. Diagnostic potential of plasmatic MicroRNA signatures in stable and unstable angina. PLoS One. 2013;8:e80345.

137. Corral-Fernández NE, Salgado-Bustamante M, MartínezLeija ME, Cortez-Espinosa N, García-Hernández MH, Reynaga-Hernández E, Quezada-Calvillo R, Portales-Pérez DP. Dysregulated miR-155 expression in peripheral blood mononuclear cells from patients with type 2 diabetes. Exp Clin Endocrinol Diabetes 2013; 121:347-53.

138. Olivieri F, Lazzarini R, Babini L, Prattichizzo F, Rippo MR, Tiano L, Di Nuzzo S, Graciotti L, Festa R, Brugè F, Orlando P, Silvestri S, Capri M, Palma L, Magnani M, Franceschi C, Littarru GP, Procopio AD. Anti-inflammatory effect of ubiquinol-10 on young and senescent endothelial cells via miR-146a modulation. Free Radic Biol Med 2013;63: 410-420.

139. Chakraborty C, Doss CG, Bandyopadhyay S, Agoramoorthy G. Influence of miRNA in insulin signaling pathway and insulin resistance: micro-molecules with a major role in type-2 diabetes. Wiley Interdiscip Rev RNA. 2014;5:697712.

140. Olivieri F, Rippo MR, Monsurrò V, Salvioli S, Capri M, Procopio AD, Franceschi C. MicroRNAs linking inflammaging, cellular senescence and cancer. Ageing Res Rev. 2013;12:1056-68.

141. Hoenicke L, Zender L. Immune surveillance of senescent cells--biological significance in cancer- and non-cancer pathologies. Carcinogenesis. 2012;33:1123-6.

142. Tchkonia T, Zhu Y, van Deursen J, Campisi J, Kirkland JL. Cellular senescence and the senescent secretory phenotype: therapeutic opportunities. J Clin Invest 2013; 123: 966-972.

143. Faraonio R, Salerno P, Passaro F, Sedia C, Iaccio A, Bellelli R, Nappi TC, Comegna M, Romano S, Salvatore G, Santoro M, Cimino F. A set of miRNAs participates in the cellular 
senescence program in human diploid fibroblasts. Cell Death Differ 2011; 19: 713-721.

144. Weilner S, Grillari-Voglauer R, Redl H, Grillari J, Nau T. The role of microRNAs in cellular senescence and agerelated conditions of cartilage and bone. Acta Orthop 2015; 86:92-9.

145. Lee S, Yu KR, Ryu YS, Oh YS, Hong IS, Kim HS, Lee JY, Kim S, Seo KW, Kang KS. MiR-543 and miR-590$3 p$ regulate human mesenchymal stem cell aging via direct targeting of AIMP3/p18. Age (Dordr) 2014;36:9724.

146. Harries LW. MicroRNAs as Mediators of the Ageing Process. Genes (Basel) 2014; 5: 656-670. doi: 10.3390/ genes5030656.

147. Yoo JK, Kim CH, Jung HY, Lee DR, Kim JK. Discovery and characterization of miRNA during cellular senescence in bone marrow-derived human mesenchymal stem cells. Exp Gerontol 2014;58:139-145. 